\title{
BIOLOGICALLY ACTIVE SUBSTANCES OF SALIX PURPUREA F. GRACILIS (GREN. \& GODR.) C.K. SCHNEID. (SALICACEAE)
}

\author{
N. Borodina, V. Kovalyov, O. Koshovyi
}

Лікарська сировина багатьох представників сімейства Salicaceае здавна широко застосовується як $в$

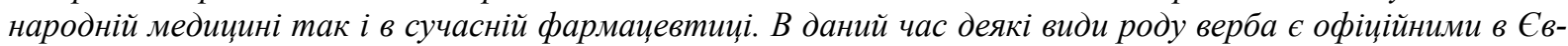
ропейських країнах. У 2014 рочі «Salicis cortex» набула статусу офіиійної лікарської сировини і включена до Державної Фармакопеї України. У зв'язку з циим актуальним є дослідження біологічно активних сполук різних видів, сортів і гібридних форм верб, щуо дозволить розширити асортимент лікарської рослинної сировини як за рахунок місцевих, так $і$ за рахунок інтродукованих видів верб, поширених в Україні.

Мета. Вивчення якісного та кількісного складу біологічно активних речовин пагонів Salix purpигеа $f$. Gracilis (Gren. \& Godr.) C.K. Schneid., щзо виростає в умовах України.

Методи дослідження. Об'єктом дослідження були сухі пагони Salix purpurea f. Gracilis (Gren. \& Godr.) C.K. Schneid. Рослинну сировину збирали в 2016-2017 роках НБС ім. М. М. Гришка НАН Украӥни.. Компонентний склад летких речовин визначали за допомогою хроматографа Agilent Technologies 6890 м масспектрометричним детектором 5973. Содержаніе суми фенольних речовин визначали колориметрически за методом Фолина-Чіокальтео. Визначення кількісного вмісту суми флавоноїдів по реакції комплексообразовання флавоноїдів з хлоридом алюмінію. Компонентний склад фенольних речовин визначали методом високоефективної рідинної хроматографії (ВЕРХ) за допомогою рідинної хроматографічної системи Prominence LC-20 Shimadzu (Японія).

Результати дослідження. Визначено якісний склад $і$ кількісний вміст летких сполук $i$ фенольних речовин пагонів Salix purpurea f. Gracilis (Gren. \& Godr.) C.K. Schneid. Встановлено, щуо сировина містить досить високі концентрації летючих сполук, серед яких переважають ароматичні - зокрема гераниол $i$ евгенол, серед терпеноїдів переважає сквален. Виявлено, щчо фенольні речовини представлені флавоноїдами і гідроксикоричні кислотами. Серед речовин фенольної природи домінують флавонони. Проведені дослідження підтверджують доиільність подальших досліджень видів верби.

Висновки. Визначено якісний склад і кількісний вміст летких сполук і фенольних речовин в пагонах Salix purpurea f. Gracilis (Gren. \& Godr.) C.K. Schneid. Проведені дослідження значно розширюють відомості щзодо хімічного складу сировини рослин роду Salix L. Отримані дані вивчення пагонів Salix purpurea $f$. Gracilis (Gren. \& Godr.) C.K. Schneid. будуть використані для планування фармакологічних досліджень та розробки МКЯ на сировину та лікарські засоби

Ключові слова: Salicaсеае, верба, пагони, біологічно активні речовини, летючі сполуки, фенольні речовини

Copyright @ 2019, N. Borodina, V. Kovalyov, O. Koshovyi.

This is an open access article under the CC BY license (http://creativecommons.org/licenses/by/4.0).

\section{Introduction}

Plant based medicines become increasingly popular along with the synthetic drugs. The medicinal raw materials of many representatives of the Salicaceae family have long been widely used both in folk medicine and in modern pharmaceuticals. Currently, some species of willow are official medicinal raw materials in some European countries. Whole or fragmented bark of young branches of different species of willow, including Salix purpurea L., Salix fragilis L., Salix daphnoides Vill. included in British Herbal Pharmacopoeia, French Pharmacopoeia, European Pharmacopoeia (including European Pharmacopoeia 7) [1]. Salix acutifolia Willd. included in the Pharmacopoeia of Russia (2008), the willow bark in 2008 is also included in the Pharmacopoeia in the Republic of Belarus. In 2014, Salicis cortex acquired the status of official medicinal raw material and was included in the State Pharmacopoeia of Ukraine [2]. In this regard, the study of biologically active compounds of different species, varieties and hybrid forms of willow is important, which will allow to expand the range of medicinal plant material both at the expense of local and at the expense of introduced species of willow, common in Ukraine.

Willows - one of the largest genera of wood species in temperate climate. It is believed that in the world there are about 350-370 species. Of these, 23-25 species are naturally growing in Ukraine $[3,4]$. In the process of evolution, willows developed a wide range of life forms, physiological features and adapted to a large variety of conditions that allow the willows to grow in a variety of places. Salix purpurea f. gracilis (gren. \& godr.) C.K. Schneid (Salix purpurea L., purple willow, purpleosier willow, Yellowstone, Purpleosier willow, Basket willow, Gracilis. This epithet most likely corresponds to S. purpurea f. Gracilis Wimm (1866), syn. S. purpurea var. gracilis Grenier \& Godron (1855), S. purpurea var. nana Dieck (1899). Female narrow-leafed cultivar (Spath, 1930) with thin branches (Rehder, 1927), v RHS HD) $[5,6]$ - shrub height up to $4 \mathrm{~m}$, branch thin, bare, greenish-or yellowish-gray or brown with a reddish tinge and a blue-tailed bloom. The buds are reddish brown, pressed into shoots. The leaves are almost opposite, oblanceolate, thinly exaggerated from above, $3-13 \mathrm{~cm}$ in length, blue- 
ish-blue or greyish-green. Blossoms in March-April, until the leaf blooms or almost simultaneously with them. Men's cat's tail are thick, cylindrical, densely coloured, large anthers of purple colour. For a bright purple coloring of cat's tail during the flowering of this willow, it was given the name "purple" [3, 4]. The area is South and Western Europe, North Africa, in the Central Europe north of the line: the Holstein, the southern coast of the Baltic Sea, Lithuania, Upper Volga, the Southern Urals, as well as Southern and Central Asia. It often grows in flood plains and forests, on wet slopes and along the banks of rivers, on wet, periodically flooded, fertile, usually limy, clay gravel, sandy and muddy soils. Having the ability to quickly settle on new substrates, willows are very common in various secondary habitats created by human activity. They easily populate potholes, quarries, embankments, sod fields and gardens. Recently, due to the high intensity of growth, some species of willow are widely grown for bioenergy purposes as solid biofuel $[4,7]$. All this substantially expands the raw material base of Salicaceae plants in Ukraine and increases the potential for their use.

2. Formulation of the problem in a general way, the relevance of the theme and its connection with important scientific and practical issues

It should be noted that although some species of willow are official in European countries, and from year 2014 also in Ukraine, there are many unresolved issues related to the rational use and chemical composition of plant raw materials of the willow flora in Ukraine, which complicates the further expansion of the raw material base and standardization of new types of medicinal plant material of the Salicaceae family [2, 8, 9]. In this regard, the study of biologically active compounds of different species, varieties and hybrid forms of willow is important, which will allow to expand the range of medicinal plant material both at the expense of local and at the expense of introduced species of willow, common in Ukraine.

3. Analysis of recent studies and publications in which a solution of the problem are described and to which the author refers

According to the literature, plants of the Salicaceae family are one of the perspective groups of plants that exhibit diverse biological properties and are used in medicine for the treatment of many diseases such as antiinflammatory, diuretic, antipyretic, disinfectant, hemostatic, astringent, sedatives, wound healing, choleretic and antirheumatic agents $[10,11]$. The antimicrobial action of drugs based on plant raw materials of Salix L. species was proved $[12,13]$. Previous studies have found that they contain different classes of natural compounds - volatile compounds, carbohydrates, amino acids, macro and microelements, lipophilic compounds [14, 15]. To date, there are a large number of works devoted to the study of compounds of phenolic nature (phenol spirometers, hydroxycinnamic and hydroxybenzoic acids, coumarins, flavonoids, tannins) [16, 17]. Previously, the authors of the article studied the volatile compounds of the leaves of Salix caprea L. Salix myrsinifolia Salisb. $[18,19]$. A chromatographic mass spectrometric study of
Salix alatusica L. raw material and lipophilic extract was performed [20]. With GC / MS methods also were studied the volatile compounds and carboxylic acids of Salix cinerea L. and Salix rosmarinifolia L. [1, 21]. The element composition of some species of the willow flora of Ukraine was determined by the method of atomic emission spectrophotometry [22].

\section{The field of research considering the general problem, which is described in the article \\ The analysis of the current state of the study of plants of the Salicaceae family of Ukrainian flora showed the need for further systematic comprehensive study of biologically active substances of new species of willow to provide a rationale for their use in medical practice.}

\section{Formulation of goals (tasks) of article}

Study of qualitative and quantitative composition of biologically active substances of Salix purpurea $f$. Gracilis (Gren. \& Godr.) C.K. Schneid., that grow in Ukraine.

\section{Presentation of the main research material (methods and objects) with the justification of the results}

The object of the study was the dry shoots of Salix purpurea f. Gracilis (Gren. \& Godr.) C.K. Schneid. Plant raw material was collected in 2016-2017 from the collection of willow of NBS named after M. M. Grishko National Academy of Sciences of Ukraine.

Chromat-mass spectrometric study of volatile components was performed on a Agilent Technology $6890 \mathrm{~N}$ chromatograph with a $5973 \mathrm{~N}$ mass spectrometric detector, with a capillary HP-5MS column (quartz, column length $30 \mathrm{~m}$, internal diameter of $0.25 \mathrm{~mm}$ ); gas carrier-helium (flow rate of $1 \mathrm{ml} / \mathrm{min}$ ). The volume of the sample is $0.1-0.5 \mu \mathrm{l}$ with a flow distribution of $1 / 50$. Thermostat temperature $50{ }^{\circ} \mathrm{C}$ with programming of $4{ }^{\circ} \mathrm{C} / \mathrm{min}$ to $220{ }^{\circ} \mathrm{C}$. The temperature of the detector and the evaporator is $250{ }^{\circ} \mathrm{C}$. The weighed material $(0.5 \mathrm{~g})$ was placed in $20 \mathrm{ml}$ of vial, and an internal standard was added. As an internal standard, tridecane was used, at a rate of $50 \mu \mathrm{g}$ per weight, followed by the calculation of the obtained internal standard concentration, which was then used for calculations. $10 \mathrm{ml}$ of water was added to the sample and volatile compounds with water vapour were distilled from it for 2 hours. using an air-cooled reflux condenser. In the process of dispersing the volatile substances adsorbed on the inner surface of the reverse refrigerator. The adsorbed substances after cooling the system were washed off by slow addition of $3 \mathrm{ml}$ of particularly pure pentane in dry vial of $10 \mathrm{ml}$. The washes were concentrated by purging $(100 \mathrm{ml} / \mathrm{min}$.) of especially pure nitrogen to a residual extract volume of $10 \mu \mathrm{l}$, which was completely removed by a chromatographic syringe. Further concentration of the test was carried out in the syringe itself to a volume of $2 \mu \mathrm{l}$. The introduction of the sample into the chromatographic column was carried out in splitless mode, in other words without separating the flow, allowing the sample to be introduced without loss of division and significantly (10-20 times) increasing the sensitivity of the chromatographic method. The determination of organic acids was also carried out 
by chromatographic mass spectrometry on a Agilent Technologies 6890 chromatograph with a $5973 \mathrm{~N}$ mass spectrometry detector. The sample was injected into a splitless chromatographic column, a rate of $1.2 \mathrm{ml} / \mathrm{min}$ injection for 0.2 minutes. The determination was carried out under the following conditions: INNOWAX capillary column, length $30 \mathrm{~m}$, internal diameter $0.25 \mathrm{~mm}$; gas carrier - helium; gas speed - carrying $1.2 \mathrm{ml} / \mathrm{min}$; temperature of the injector heater $-250{ }^{\circ} \mathrm{C}$, temperature of the thermostat with programming $4{ }^{\circ} \mathrm{C} / \mathrm{min}$ from $50{ }^{\circ} \mathrm{C}$ to $250{ }^{\circ} \mathrm{C}$; detector temperature $250{ }^{\circ} \mathrm{C}$. The identification of the substances was carried out by comparing the mass spectra of the compounds with the data from the NIST05 and WILEY 2007 mass spectrum libraries in combination with the AMDIS and NIST identification programs. For the quantitative calculations, the internal standard method was used. The calculation of the content of the components was carried out according to the formula: $\mathrm{C}=\mathrm{K} 1 * \mathrm{~K} 2, \mathrm{mg} / \mathrm{kg}$, where $\mathrm{K} 1=\mathrm{P} 1 / \mathrm{P} 2(\mathrm{P} 1-$ peak area of the investigated substance, $\mathrm{P} 2$ - area of the peak of the standard), K2=50/M (50 - mass of internal standard, $\mu \mathrm{g}$; introduced as a sample; $\mathrm{M}$ is a sample weight, g). Quantitative determination of substances was expressed in $\mathrm{mg} / \mathrm{kg}$ of raw material [1, 19, 21, 23].

34 components identified in the investigated raw material were identified. Results of determining the content of volatile substances in raw willow are presented in Fig. 1 and in Table 1.

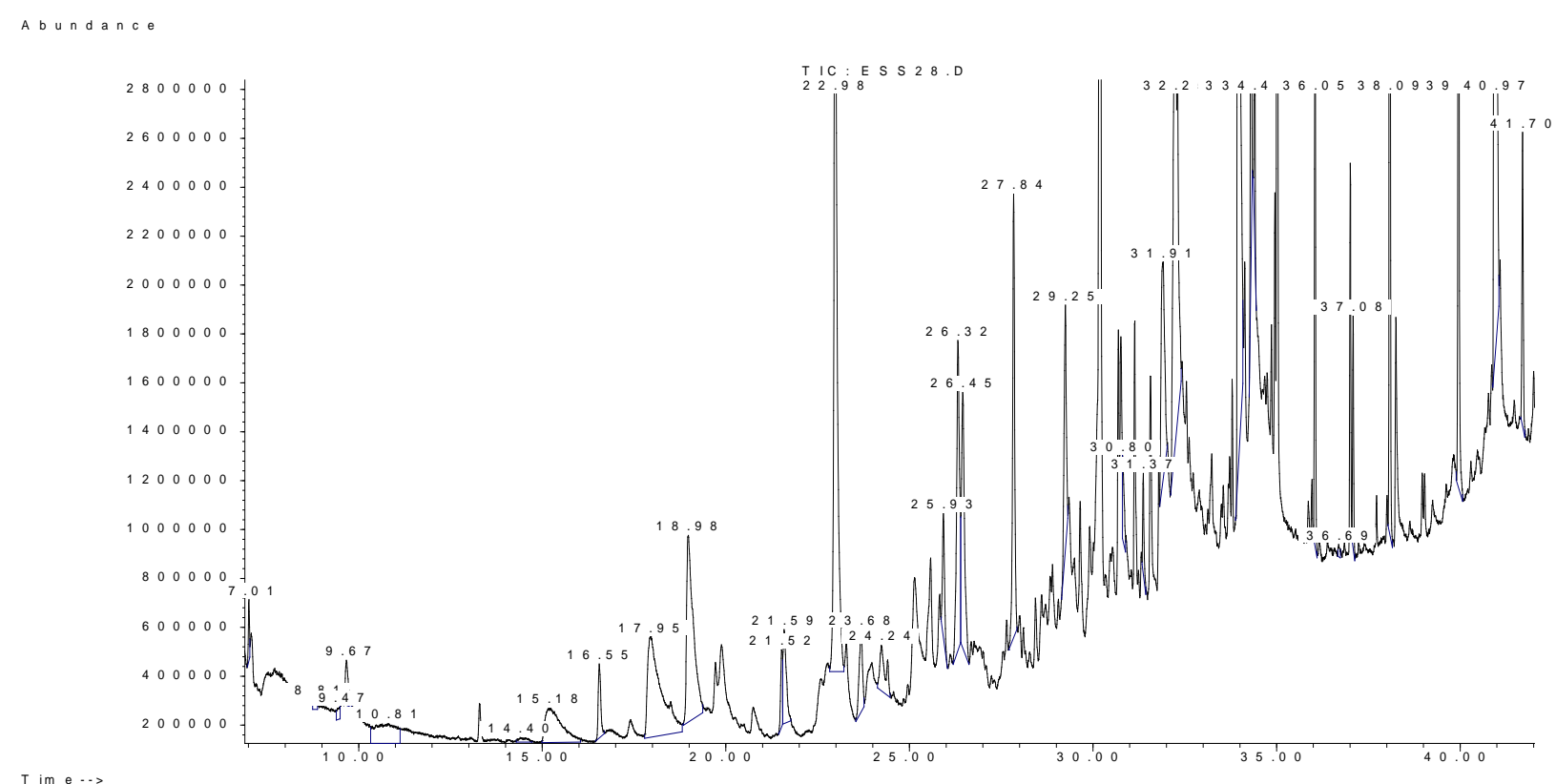

Fig. 1. Chromatogram of volatile compounds of Salix purpurea f. Gracilis (Gren. \& Godr.) C.K. Schneid shoots.

Among the identified compounds, aromatic compounds, sesquiterpene compounds, aliphatic alcohols, alkanes, terpenes, hydrocarbons, fatty acids and their derivatives, aldehyde isomers, and oxygen-containing compounds have been identified. Aromatic compounds of raw material of purple willow are represented by biologically active substances, including 2hydroxybenzaldehyde, phenylethyl alcohol, geraniol, eugenol, 2,4-bis (1,1-dimethylethyl) phenol. Among terpene compounds dominated squalene $((2,6,10,15,19,23$-hexamethyltetracoza-2,6,10,14,18,22hexaene) - acyclic triterpene). Among other compounds, significant amounts of fatty acids and their derivatives, in the total amount of fatty acids, are found in the largest number of palmitic acid.

Component composition of phenolic compounds was determined by the method of high-performance liquid chromatography (HPLC). For extraction of polyphenols, samples of raw materials were pre-triturated in a mortar to a powdered state. To the weighted sample $60 \%$ isopropanol was added in a ratio of $1 \mathrm{~g}$ of the sample to $20 \mathrm{ml}$ of isopropanol solution.

Extraction was carried out in sealed containers for 5 days at room temperature with periodic stirring according to the method [14]. Extraction was carried out in the dark to prevent the transformation of extracted substances under the influence of light. The extracts were filtered before analysis using a Supelco Iso-Disc Filters PTFE 25-4 (25mm x $0.45 \mu \mathrm{m})$ syringe filter [24-26].

The extract was analyzed by high performance liquid chromatography (HPLC) using the Prominence LC-20 Shimadzu Liquid Chromatographic System (Japan), consisting of the following functional modules: DGU-20A3 degasser, LC-20AD pump module, SIL20AC auto-sampler refrigerator, photometric Detector SPD-20AV, column of thermostat CTO-20A, column Agilent Technologies Microsorb-MV-150 (turnedphase, silica gel with sewn group $\mathrm{C} 18$ (- $(\mathrm{CH} 2)$ $17 \mathrm{CH} 3)$, length $150 \mathrm{~mm}$, diameter $4.6 \mathrm{~mm}$, size of sorbent grains $5 \mu \mathrm{m}$ ). 
Table 1

Component composition of volatile compounds of Salix purpurea f. Gracilis (Gren. \& Godr.) C. K. Schneid shoots

\begin{tabular}{|c|c|c|c|}
\hline No. & Retention time, $\min$ & Component & Content, $\mathrm{mg} / \mathrm{kg}$ \\
\hline 1 & 7.012 & 2-oxybenzaldehyde & 9.68 \\
\hline 2 & 8.816 & trans-linalool oxide & 4.59 \\
\hline 3 & 9.472 & cis-linalool oxide & 4.51 \\
\hline 4 & 9.664 & linalool & 18.62 \\
\hline 5 & 10.805 & phenylethyl alcohol & 59.47 \\
\hline 6 & 14.398 & citronellol & 5.37 \\
\hline 7 & 15.177 & geraniol & 77.46 \\
\hline 9 & 17.945 & eugenol & 187.58 \\
\hline 10 & 18.978 & leden oxide & 171.34 \\
\hline 11 & 21.515 & $\beta$-ionone-5,6-epoxide & 17.13 \\
\hline 12 & 21.584 & $\beta$-ionone & 42.28 \\
\hline 13 & 22.98 & 2,4-bis (1,1-dimethylethyl)-phenol & 354.57 \\
\hline 14 & 23.682 & isoaromadendrene epoxide & 37.49 \\
\hline 15 & 24.237 & nerolidol & 35.16 \\
\hline 16 & 25.925 & cubenol & 35.47 \\
\hline 17 & 26.318 & $\beta$-eudesmol & 130.07 \\
\hline 18 & 26.45 & $\alpha$-eudesmol & 109.27 \\
\hline 19 & 27.837 & tetradecanal & 92.37 \\
\hline 20 & 29.248 & myristic acid & 55.23 \\
\hline 21 & 30.806 & pentadecanoic acid & 13.36 \\
\hline 22 & 31.369 & methyl palmitate & 13.17 \\
\hline 23 & 31.908 & palmitoleic acid & 79.14 \\
\hline 24 & 32.248 & palmitic acid & 240.88 \\
\hline 25 & 33.944 & phytol & 305.31 \\
\hline 26 & 34.306 & ethyl linoleate & 62.57 \\
\hline 27 & 34.399 & oleic acid & 29.04 \\
\hline 28 & 36.049 & tricosan & 71.60 \\
\hline 29 & 36.689 & tetracosan & 2.14 \\
\hline 30 & 37.082 & pentacosan & 25.04 \\
\hline 31 & 38.084 & hexacosan & 149.23 \\
\hline 32 & 39.958 & heptacosan & 122.48 \\
\hline 33 & 40.976 & squalene & 924.98 \\
\hline 34 & 41.7 & nonacosane & 38.30 \\
\hline
\end{tabular}

HPLC conditions:

1) Composition of the mobile phase (eluent): methanol and $0.9 \%$ solution of phosphoric acid in deionized water (reagents Sigma-Aldrich, Germany).

2) Chromatography mode - gradient. Chromatography - gradient mode, was developed for the qualitative separation of certain phenolic acids and flavonoids in plant extracts [18, 23]. Initial ratio of eluent components: 1:9. The content of methanol in the eluent during the analysis varied according to the following scheme: - the first 13 minutes - increase from 10 to $40 \%$; from the 13th to the 20th minute - increase from 40 to $53 \%$; from 20th to 26th minute - increase from 53 to $55 \%$; from the 26th to the 40th minute - holding $55 \%$; from the 40th to the 41 st minute - down to $10 \%$; from the 41 st to the 56th minute - holding $10 \%$.

3) The velocity of the eluent $-0.5 \mathrm{ml} / \mathrm{min}$.

4) Column temperature $-400 \mathrm{C}$.

5) The volume of the entered sample $-5 \mu \mathrm{l}$.

The identification of the substances in the extract was carried out by comparing the holding time and the spectral characteristics of the test substances with similar characteristics of the standards according to the method of identification of polyphenols [17], for which the chromatography was carried out at wavelengths 225 , 255, 286 and $350 \mathrm{~nm}$ [25, 27, 28]. For precise identification or identification of the substances belonging to the specific groups of polyphenols, standard samples were used: chlorogenic and coffee acids, catechins, flavonols quercetin and rutin, flavanones naringenin, naringin and hesperetin, hesperidine, luteolin and apigenin flavones, anthocyanin cyanidin (Sigma-Aldrich, Germany). Identification characteristics of the listed standards were obtained under the above described conditions of chromatography. Gauge dependencies "peak area - content of the standard" had a linear appearance with an accuracy of not less than $r^{2}=0.994$.

Determination of the content of substances with established affiliation with specific groups of polyphenols, conducted using standards, the degree of similarity with which was the largest, taking into account the chemical form of the substance (aglycone, glycoside). Substances whose degree of similarity to any standard was below $70 \%$ belonged to the group of unidentified substances, and their content was determined by standards, the degree of similarity with which was the largest. The 
total content of polyphenols was determined by summing the content of substances found in the range of peaks of flavonoids and phenolic acids on chromatograms [26, 29-31].

In the study of phenolic compounds of Salix purpurea f. Gracilis (Gren. \& Godr.) C.K. Schneid found that their total content in the raw material was $32582.98 \mu \mathrm{g} / \mathrm{g}$. Phenolic compounds of this type of willow are represent- ed by hydroxycinnamic acids and flavonoids. The unidentified substances were $990.14 \mu \mathrm{g} / \mathrm{g}$. The sum of flavonoids was $27974.77 \mu \mathrm{g} / \mathrm{g}$, among which the flavanones $21178.17 \mu \mathrm{g} / \mathrm{g}$ are dominant, which is consistent with the results of previous studies. A more detailed representation of the composition of substances in the samples under study gives the results shown in Table 2 and on Fig. 2.

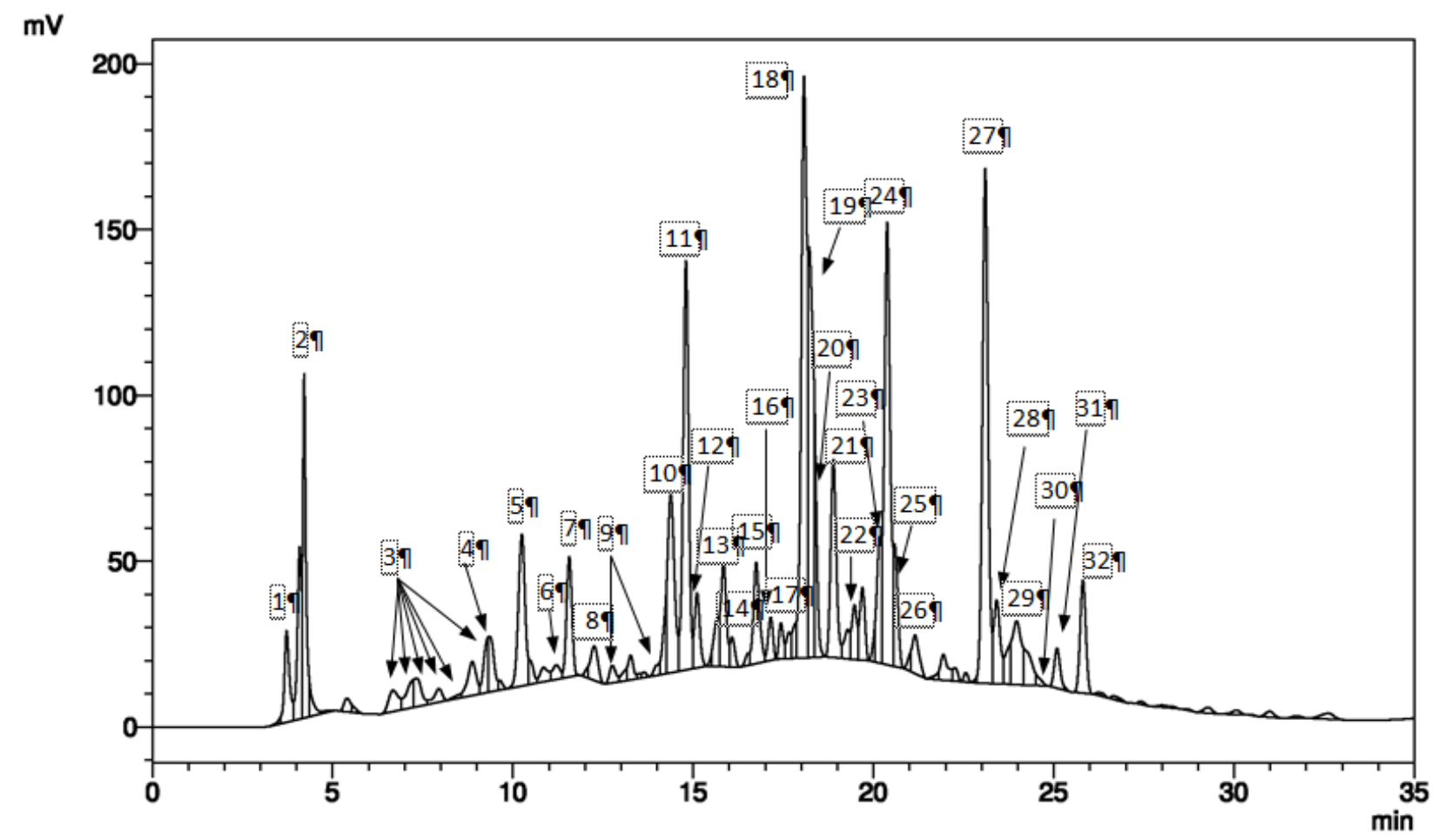

Fig. 2. Chromatogram of compounds of Salix purpurea f. Gracilis (Gren. \& Godr.) C.K. Schneid shoots at $255 \mathrm{~nm}$, Axis $\mathrm{X}-\mathrm{T}$, min.: Retention time, min., Axis $\mathrm{Y}$ - Absorption, $\mathrm{mV}, 1,2,3,29$ - catechin-like substances, 4 - catechin, 5, 7 - naringin glycosides, 6 - chlorogenic acid, 8, 10, 14, 16 - catechins, 9 - phenolic acids, 11, 12, 26 - hesperetin glycosides, 13, 15 - naringenin glycosides, 17 -flavonols glycosides, 18, 20, 24, 25 - luteolin glycosides, 19 - routine, 21 - hesperidin, 22, 32 - apigenin glycosides, 23 - myricetin glycosides, 27 - luteolin, 28 - hesperetin, 30 - flavonols aglycones, 31 - apigenin

Table 2

Component composition of phenolic compounds of Salix purpurea f. Gracilis (Gren. \& Godr.) C.K. Schneid shoots

\begin{tabular}{|c|c|c|c|}
\hline Group of polyphenols & Content, $\mu \mathrm{g} / \mathrm{g}$ & Separate compounds & Content, $\mu \mathrm{g} / \mathrm{g}$ \\
\hline \multirow{2}{*}{ Phenolic acids } & \multirow{2}{*}{200.06} & chlorogenic acid & 125.63 \\
\hline & & caffeic acid & - \\
\hline Catechins & 2160.58 & catechin & 982.96 \\
\hline Catechin-like & 3304.94 & & \\
\hline \multirow{4}{*}{ Flavonols } & \multirow{4}{*}{1651.57} & routine & 1279.62 \\
\hline & & quercetin & - \\
\hline & & myricetin glycosides & 245.69 \\
\hline & & myricetin & - \\
\hline \multirow{4}{*}{ Flavonones } & \multirow{4}{*}{21178.17} & naringin & 369.34 \\
\hline & & naringenin & 9.72 \\
\hline & & hesperidin & 4558.65 \\
\hline & & hesperetin & 52.79 \\
\hline \multirow{4}{*}{ Flavones } & \multirow{4}{*}{3097.52} & luteolin glycosides & 1753.86 \\
\hline & & luteolin & 762.19 \\
\hline & & apigenin glycosides & 447.89 \\
\hline & & apigenin & 133.58 \\
\hline Unidentified & 990.14 & & \\
\hline The sum of polyphenols & 32582.98 & & \\
\hline
\end{tabular}


Determination of the quantitative content of the amount of phenolic compounds using a Folin's reagent [26].

Previously prepared:

- reagent $\mathrm{A}-2 \% \mathrm{Na}_{2} \mathrm{CO}_{3}$ solution in $0.1 \mathrm{~N}$ $\mathrm{NaOH}$ solution;

- Folin's reagent "Fluka" diluted with water 1:1;

- control on a reagent containing $0.4 \mathrm{ml}$ of reagent $\mathrm{A}, 0.4 \mathrm{ml}$ of $70 \%$ ethanol and $0.4 \mathrm{ml}$ of Folin's reagent.

To $0.4 \mathrm{ml}$ of the extract was added $4 \mathrm{ml}$ of Reagent A, and then, after stirring, $0.4 \mathrm{ml}$ of Folin's reagent. At the spectrophotometer, after 30 minutes at a wavelength of $750 \mathrm{~nm}$, the intensity of the coloration against the control of the reagents was determined. Spectrophotometric analysis was performed on a UVmini-1240 Shimadzu spectrophotometer (Japan).

The amount of phenolic compounds in the extract was calculated by the formula:

$$
C=\frac{E \cdot n \cdot V}{K \cdot m}
$$

where: $\mathrm{C}$ - the content of phenolic compounds in $\mu \mathrm{M} / \mathrm{g}$ sample; $\mathrm{E}$ - extinction; $\mathrm{n}$ - breeding; $\mathrm{K}$ - coefficient of recalculation of extinction in $\mathrm{mg}$ routine; $\mathrm{V}$ - amount of extractant in $\mathrm{ml} ; \mathrm{m}$ - mass of raw materials in grams.

Coefficient $\mathrm{K}$ was calculated from the calibrated curve, which is constructed by routine solutions at concentrations of $0.25 ; 0.10 ; 0.025$ and $0.005 \mathrm{mg} \mathrm{ml}$.

Results of quantitative determination of phenolic compounds in Salix purpurea f. Gracilis (Gren. \& Godr.) C.K. Schneid is presented in Table 3.

4. Determination of the quantitative content of the amount of flavonoids by the reaction of complexation of flavonoids with aluminium chloride [26, 28].

To $0.5 \mathrm{ml}$ of the extract was added $0.5 \mathrm{ml}$ of a $5 \%$ solution of aluminium chloride in $96 \%$ ethanol and $3 \mathrm{ml}$ of $96 \%$ ethanol and cooled.

After 40 minutes, the optical density of the solution was measured at a wavelength of $410.5 \mathrm{~nm}$ on the spectrometer UVmini-1240 Shimadzu (Japan)

The content of flavonoids in terms of routine was calculated according to the formula

$$
C=\frac{E_{0} \cdot C_{r s} \cdot V_{e}}{E_{r s} \cdot m_{s}},
$$

where $\mathrm{C}$ - content of flavonoids in $\mathrm{mg} / \mathrm{g}$ of dry sample; $E_{o}$ is the optical density of the solution of the sample; $E_{r s}$ is the optical density of the solution of the comparison; $\mathrm{C}_{\mathrm{rs}}$ is the concentration of the comparison solution equal to $0.1 \mathrm{mg} / \mathrm{ml} ; \mathrm{m}_{\mathrm{s}}$ - weighted dry sample in grams; $\mathrm{V}_{\mathrm{e}}-$ volume of extract in $\mathrm{ml}$.

Results of quantitative determination of flavonoids in Salix purpurea f. Gracilis (Gren. \& Godr.) C.K. Schneid shoots is shown in the Table 3

Table 3

Content of phenolic compounds and flavonoids in Salix purpurea f. Gracilis (Gren. \& Godr.) C.K. Schneid shoots

\begin{tabular}{|c|c|}
\hline $\begin{array}{c}\text { Content of flavonoids, } \\
\mathrm{mg} / \mathrm{g}\end{array}$ & $\begin{array}{c}\text { Content of phenolic com- } \\
\text { pounds, } \mu \mathrm{Mol} / \mathrm{g}\end{array}$ \\
\hline $28.02 \pm 0.51$ & $174.59 \pm 1.89$ \\
\hline
\end{tabular}

Statistical processing was performed according to generally recognized methods [2, 8]. Differences between experimental and control variants were considered significant at $\mathrm{p}<0.05$.

7. Conclusions from the conducted research and prospects for further development of this field

1. Qualitative composition and quantitative content of volatile compounds and phenolic substances in the Salix purpurea f. Gracilis (Gren. \& Godr.) C.K. Schneid shoots have been determined.

2. Studies conducted considerably expand the information on the chemical composition of raw materials of plants of the genus Salix L. Obtained data on the study of Salix purpurea f. Gracilis (Gren. \& Godr.) C.K. Schneid will be used for the planning of pharmacological research and development of MQC for raw materials and medicines.

\section{Acknowledgment}

The authors express their sincere gratitude to the curator of the site "Moisture-loving plants" PhD O.M. Gorelov for the assistance.

\section{References}

1. Borodina N. V. Research of volatile compounds from Salix cinerea L // // Oxford Review of Education and Science. 2016. Vol. V, Issue 1 (11). P. 468-473.

2. Derzhavna Farmakopeia Ukrainy. Vol. 1. Kharkiv: Derzhavne pidpryiemstvo «Ukrainskyi naukovyi farmakopeinyi tsentr yakosti likarskykh zasobiv», 2015. $1128 \mathrm{p}$.

3. Dendroflora Ukrainy. Dykorosli y kultyvovani dereva i kushchi. Pokrytonasinni. Chastyna I. Dovidnyk / Kokhno M. A., Parkhomenko L. I., Zarubenko A. U. et. al.; ed. by Kokhno M. A. Kyiv: Fitosotsiotsentr, 2002. 448 p.

4. Fuchylo Ya. D., Sbytna M. V. Vepby Ukpainy (biolohiia, ekolohiia, vykopystannia): monograph. Kyiv: Lohos, 2009. 200 p.

5. Checklist for cultivars of Salix L. (willow) International Salix Cultivar Registration Authority FAO. International Poplar Commission, 2015. 163 p.

6. Chen-Fu F., Skvortsov A. K. Validation of Hao's new Chinese taxa in Salix (Salicaceae) // Novon. 1998. Vol. 8 , Issue 4. P. 467-470. doi: http://doi.org/10.2307/3391877

7. Enerhetychna verba: tekhnolohiia vyroshchuvannia ta vykorystannia / Roik M. V., Sinchenko V. M., Fuchylo Ya. D. et. al.; ed. by Sinchenko V. M. Vinnytsia: TOV «Nilan - LTD», 2015. 340 p.

8. Derzhavna Farmakopeia Ukrainy. Vol. 3. Kharkiv: Derzhavne pidpryiemstvo «Ukrainskyi naukovyi farmakopeinyi tsentr yakosti likarskykh zasobiv», 2014. $732 \mathrm{p}$.

9. European Pharmacopoeia. Council of Europe, European Department for the Council of Medicines. Strasbourg, 2005. 
10. Kodakova M. N., Dubishhev A. V. Sravnitelnaia otsenka farmakologicheskogo effekta rastitelnykh preparatov semeistva ivovykh // Meditsinskii vestnik Bashkortostana. 2009. Vol. 4, Issue 2. P. 193-196.

11. Frolova O. O., Kompantseva E. V., Dementieva T. M. Biologically Active Substances of Plants from Sali x L. Genus // Pharmacy \& Pharmacology. 2016. Vol. 4, Issue 2 (15). P. 41-59. doi: http://doi.org/10.19163/2307-9266-2016-4-2(15)-41-59

12. Zhebrak I. S., Tsybulko E. V. Antimikrobnaia aktivnost vodnykh nastoev kory Salix purpurea L: proceeding // Aktualnye problemy ekologii. Grodno: GrGU, 2010. P. 35-37.

13. Rasteniia semeistva ivovykh - perspektivnyi istochnik novykh antimikrobnykh, protivovospalitelnykh i toniziruiushhikh lekarstvennykh sredstv: proceeding / Kurkin V. A. et. al. // Poisk, razrabotka i vnedrenie novykh lekarstvennykh sredstv i organizatsionnykh form farmatsevticheskoi deiatelnosti. Tomsk, 2000. P. 42-43.

14. Borodina N. V. Izuchenie letuchikh komponentov Salix caprea L // Proceedings of 4-th European Conference on Biology and Medical Sciences. Vienna, 2015. P. 209-213.

15. Borodina N. V., Kovalev V. N., Koshevoi O. N. Sravnitelnyi analiz aminokislotnogo sostava pobegov Salix purpurea L., Salix viminalis L., Salix fragilis L // Vestnik Iuzhno-Kazakhstanskoi gosudarstvennoi farmatsevticheskoi akademii. 2014. Vol. 4, Issue 3 (68). P. 53-55.

16. Borodina N. V., Kovalev V. N. Sravnitelnyi analiz fenolnykh soedinenii pobegov Salix caprea L., Salix purpurea L., Salix viminalis L. flory Ukrainy: proceeding // Fenolnye soedineniia: fundamentalnye i prikladnye aspekty. Moscow, 2015. P. $27-33$.

17. Borodina N. V. Fenolni spoluky Salix matsudana Koidz: proceeding // Vesniani naukovi chytannia. Kyiv: Tsentr naukovykh publikatsii, 2017. P. 129-136.

18. Borodina N. V. Khromato-mass-spektrometrycheskoe yzuchenye lystev Salix caprea L: proceeding // Aktualni pytannia rozvytku medychnykh nauk u XXI st. Lviv: Lvivska medychna spilnota, 2015. P. 106-108.

19. The study of Salix myrsinifolia Salisb. leaves by the GC/MS method / Borodina N. V., Kovalyov V. N., Koshovyi O. N., Stremoukhov A. A. // The 9th International Conference on Pharmaceutical Sciences and Pharmacy Practice, dedicated to the 100th years anniversary of independent Lithuania's pharmacy. Kaunas: LSMU, 2018. P. 105.

20. Borodina N. V., Kovalov V. M. Khromato-mas-spektrometrychne doslidzhennia syrovyny ta lipofilnoho ekstraktu Salix alatavica: proceeding // Teoretychni ta praktychni aspekty doslidzhennia likarskykh roslyn. Kharkiv, 2018. P. 43-44.

21. Borodina N., Koshovyi O., Kovalyov V. The chromatography-mass spectrometry study of Salix rosmarinifolia L // Azerbaidzhanskii farmatsevticheskii i Farmakoterapevticheskii zhurnal. 2016. Vol. XVI, Issue 2. P. 15-20.

22. Borodina N. V., Kovalov V. M. Mineralnyi sklad deiakykh vydiv rodyny Salicaceae // Zbirnyk naukovykh prats spivrobitnykiv NMAPO im. P. L. Shupyka. 2018. Issue 29. P. 180-187.

23. Chernogorod L. B., Vinogradov B. A. Efirnye masla nekotorykh vidov roda Achillea L., soderzhashhie fragranol // Rastitelnye resursy. 2006. Vol. 42, Issue 2. P. 61-68.

24. Levytskyi A. P., Khodakov Y. V., Raitseva E. S. Ekstraktsyia polyfenolov yz lystev vynohrada // Kharchova nauka i tekhnolohiia. 2012. Vol. 20, Issue 3. P. 36-37.

25. Sposib identyfikatsii polifenoliv v roslynnykh ekstraktakh: Pat. No. 80597 UA. MPK (2013.01) G01N 33/00 / Khodakov I. V., Levytskyi A. P., Makarenko O. A. No. u 201212473; declareted: 31.10.2012; published: 10.06.2013. Bul. No. 11.

26. Frukty, ovochi ta produkty yikh pererobliannia. Metody vyznachennia polifenoliv. DSTU 4373:2005 (Natsionalnyi standart Ukrainy). Kyiv: Derzhspozhyvstandart Ukrainy, 2006. 6 p.

27. Vertikova E. K., Khodakov I. V., Levitskii A. P. Metod opredeleniia khlorogenovoi kisloty // Visnik stomatologii. Spets. vipusk. 2010. Vol. 73, Issue 5. P. 2-5.

28. Kilkisne vyznachennia flavonoidiv u losionakh dlia likuvannia infektsiinykh zakhvoriuvan shkiry / Rekhletska O. V., Kalyniuk T. H., Hudz N. I., Fedushchak N. K. // Medychna khimiia. 2007. Vol. 9, Issue 2. P. 87-905.

29. Khodakov I. V. Sposob identifikatsii polifenolov v rastitelnykh ekstraktakh pri pomoshhi VEZHKH. Opredelenie sostava izoflavonov soi // Metody i obekty khimicheskogo analiza. 2013. Vol. 8, Issue 3. P. 132-142.

30. Khodakov I. V. Sposob identifikatsii polifenolov v rastitelnykh ekstraktakh // Visnik stomatologii. Spets. vip. 2012. Vol. 80, Issue 7. P. 42.

31. Sortovye osobennosti soi ukrainskoi selektsii po soderzhaniiu polifenolov v listiakh / Khodakov I. V., Makarenko O. A., Levitskii A. P., Sichkar V. I. // Fiziologiia rastenii i genetika. 2014. Vol. 46, Issue 1. P. 27-36.

Received date 21.05.2019

Accepted date 10.06.2019

Published date 28.06.2019

Natalia Borodina PhD, Associate Professor, Department of Pharmacognosy, National University of Pharmacy Pushkinska str., 53, Kharkiv, Ukraine, 61002

E-mail: natalijaborodina@gmail.com

Volodimir Kovalyov, Doctor of Pharmaceutical Sciences, Professor, Department of Pharmacognosy, National University of Pharmacy, Pushkinska str., 53, Kharkiv, Ukraine, 61002

E-mail: gnosy@nuph.edu.ua

Oleh Koshovyi, Doctor of Pharmaceutical Sciences, Professor, Head of Department, Department of Pharmacognosy, National University of Pharmacy, Pushkinska str., 53, Kharkiv, Ukraine, 61002

E-mail: oleh.koshovyi@gmail.com 